\title{
CHARACTERISTICS OF WATER AND WETLAND PLANTS OF THE WATER RESERVOIRS IN THE UMCS BOTANICAL GARDEN IN LUBLIN, POLAND
}

\author{
Agnieszka Dąbrowska
}

\author{
Botanical Garden, University of Marie Curie-Sklodowska in Lublin \\ Slawinkowska 3, 20-810 Lublin, Poland \\ e-mail: agnieszka.dabrowska@ poczta.umcs.lublin.pl
}

Received: 02.10.2013

\begin{abstract}
The aim of the study was to compile an inventory and determine the ecological characteristics of the spontaneous flora of the restored water reservoirs and their wet banks in the western part of Lublin in the years 1997-2013. The study objects are small reservoirs located at the UMCS Botanical Garden in the Czechówka River valley. These ponds are subjected to strong anthropogenic pressure. 68 plant species from 33 families and 58 genera were recorded in the flora of the ponds and their wet banks. An important feature of the described water bodies is the large proportion of native species (94\% of the flora). Cryptophytes and hemicryptophytes as well as biological groups combining the features of hemicryptophytes and cryptophytes are the predominant life forms. Perennials account for $80 \%$ of the flora. The ponds and their wet banks are inhabited by 25 medicinal and 19 bee forage plants.
\end{abstract}

Key words: floristic diversity, urban reservoirs, river valley

Running head: Characteristics of water and wetland plants of the water reservoirs in Lublin

\section{INTRODUCTION}

River valleys in the temperate zone are the best model for investigations of species diversity, synanthropisation processes, and flora dynamics. This is associated with the remarkable diversity of the natural habitat and the centuries-long history of human management of riverside areas. River valleys perform the role of ecological corridors [1] and frequently function as diversity centers [2,3]. Particularly important is the susceptibility of riparian ecosystems to invasion of alien plant species [4,5]. In the recent years, considerable attention has been devoted to conservation and protection of urban river valleys [6,7]. An exam- ple of such an area is the fragment of the Czechówka River valley with two ponds within the administrative boundaries of the Botanical Garden of Maria Curie-Skłodowska University (UMCS). The ponds are fed with the Czechówka River waters. The river is $18 \mathrm{~km}$ long and its catchment covers an area of $78.5 \mathrm{~km}^{2}$. The Czechówka is a fourth order river and a left tributary of the Bystrzyca River. Although there are many springs in its upper course, their low water discharge provides low amounts of water in both the Czechówka and its tributary, Łazęga River [8]. This situation is related to the lowered underground water table as a result of ongoing exploitation of underground waters by the "Sławinek" water utility (since 1961). The exploitation of underground waters reduced river recharge and simultaneously contributed to water escape from the riverbed [9]. The formation of a depression sink at the end of the 80 's of the $20^{\text {th }}$ century led to the periodic disappearance of the Czechówka River and drying out of the ponds in the Botanical Garden. The change in the water relations resulted in the extinction of valuable pond plant and animal species. This fragment of the valley lost its landscape values for over 10 years. In 1996 and 2000, the ponds were revitalised using the latest technology for bottom sealing [10]. Polish flora species and species originating from various regions of the world were gradually introduced to the restored water bodies. Additionally, fragmented communities of spontaneophytes inhabited the ponds with varying intensity.

The aim of the study was to compile an inventory and assess the ecological characteristics of the spontaneous flora of the restored water reservoirs and their wet in the UMCS Botanical Garden in Lublin in the years 1997-2013. 


\section{MATERIALS AND METHODS}

\section{The characteristics of the study area}

The investigated water reservoirs are situated in a historical region of the western part of Lublin, $51^{\circ} 15.629^{\prime} \mathrm{N}, 22^{\circ} 30.975^{\prime}$ E. Archival materials show that they were important landscape features in the "Slawinek" health resort at the turn of the $19^{\text {th }}$ and $20^{\text {th }}$ centuries. After the health resort had been closed down (1917), the park with the ponds in Sławinek village became a popular place for rest and recreation among Lublin's inhabitants. In 1965 the UMCS Botanical Garden was established in the area of the health resort park. Plant displays were prepared and the ponds were renovated in 1967 [11]. The ponds were also revitalised in 1996 and 2000. In 1996 the larger 0.8-ha pond was reconstructed (locality A) and its bottom was sealed with a polypropylene matt filled with sodium bentonite. In 2000 the other pond, covering an area of 0.5 ha (locality B), was renovated using the same technology [10]. Sodium bentonite is a sedimentary rock primarily composed of sodium montmorillonite, an alkaline mineral that affects aquatic environments. In the south, the ponds border an expressway (Solidarności Alley) and a housing district behind the road. The south-western part of the pond area borders Warszawska Alley, while the western and northern parts neighbour the terrace slope of the Czechówka River valley. The inclined slope is inhabited by Acer platanoides L., Aesculus hippocastanum L., Carpinus betulus L., Fraxinus excelsior L., Robinia pseudoacacia L., Sambucus nigra L., Tilia cordata Mill., and Ulmus minor Mill. The surface area of the ponds is 0.8 ha and $0.5 \mathrm{ha}$, whereas their average and maximum depths are $1.1 \mathrm{~m}$ and $1.7 \mathrm{~m}$, respectively (Fig. 1). The ponds are not intended for fishery management. Their high fertility leads to degradation of water quality (blue-green algae), which in turn affects fish populations.

\section{Methods}

Floristic explorations of the ponds and their banks (up to a height of $1 \mathrm{~m}$ ) were performed three times in each season (April, June, and August) in the years 1997-2013 in pond A and 2000-2013 in pond B (Table 1). The nomenclature is consistent with that proposed by Index Kewensis [12]. Families and genera as well as species within the genera follow the systematic order. The geographical-historical status of the taxa follows the papers by $\mathrm{Chmiel}$ [13] and $\mathrm{Jackowiak}$ [14]. The papers of $\mathrm{Zaj}$ ą c [15] and $\mathrm{Zaj}$ ąc et al. [16] were consulted in the case of alien species. Classification of life forms (according to Raunkiaer) was found in the work of $\mathrm{Zarzycki}$ et al. [17]. Classification into medicinal and bee forage plant groups follows that defined by P o d b i e l k o w - ski and Sudnik-Wójcikowska [18], Kołtowski [19], and Lipiński [20]. The indices of anthropogenic changes in the flora were calculated according to the following formulae ( $\mathrm{N}$ denotes the number of all taxa investigated) [14,21]:

- the index of synanthropisation = ApNo (number of apophytes) + AlienNo (number of anthropophytes) $* 100 / \mathrm{N}$,

- the index of apophytisation $=\mathrm{ApNo} * 100 / \mathrm{N}$,

- the index of anthropophytisation $=$ AlienNo $* 100 / \mathrm{N}$.

The rate of floristic changes in both water bodies was determined using the Jaccard species similarity index [13]. In 2005, 2008, and 2013, the abundance degree was determined for the spontaneous species using a five-grade scale (Table 1).

\section{RESULTS}

In total, 68 vascular plant species from 33 families and 58 genera were identified in the ponds (Table 1). A majority of the plants are angiosperms and they account for $98 \%$ of all the species. Dicotyledonous plants are represented by 40 taxa (59\%) and monocotyledons by 27 taxa (39\%). Cryptogamous plants are represented by Equisetum palustre. The number of species in the individual families ranged from 1 to 9 . Families represented by the largest number of species include Poaceae (9 species), Compositae (7), Cyperaceae (5), followed by Brassicaceae, Boraginaceae, Lamiaceae, Scrophulariaceae and Lemnaceae (3). The three species-richest families constitute $31 \%$ of the entire flora ( 21 species). 18 families were represented by one species only. Carex is the species-richest genera (3 species).

The spontaneous flora of the investigated sites is dominated by native species, which account for $94 \%$ of the flora (64 species) (Tables 1 and 2). The synanthropisation index is $62 \%$. Lower values $(56 \%)$ are reported for the apophytisation index. Only four alien species were found. This group includes one archeophyte, $A r$ moracia rusticana, and three kenophytes, Impatiens parviflora, Elodea canadensis, and Solidago canadensis. The anthropophytisation index reaches $6 \%$.

The analysed flora is dominated by hemicryptophytes and cryptophytes (37 species, $54 \%$ of the flora) (Tables 1 and 2). Other notable biological groups are composed of plants that combine the characteristics of hemicryptophytes and cryptophytes (18 species, 26\% of the flora). Perennials account for $80 \%$. The proportion of therophytes is considerably lower (6\%), but they dominate over phanerophytes $(5 \%)$ and chamaephytes (3\%). The least important role in this inventory is played by plants exhibiting combined characteristics of chamaephytes, hemicryptophytes and therophytes. 
Table 1

List of species and ecological characteristics of spontaneous flora in the water reservoirs and their wet banks in the UMCS Botanical Garden in Lublin

\begin{tabular}{|c|c|c|c|c|c|c|c|c|}
\hline \multirow{3}{*}{ Family name and species } & \multirow{2}{*}{\multicolumn{2}{|c|}{$\begin{array}{c}\begin{array}{c}\text { Year of appearance } \\
\text { of species }\end{array} \\
\text { Locality }\end{array}$}} & \multirow{3}{*}{ GHs } & \multirow{3}{*}{ LF } & \multirow{3}{*}{ UF } & \multicolumn{3}{|c|}{$\begin{array}{l}\text { Abundance of plants } \\
\text { in the years: }\end{array}$} \\
\hline & & & & & & \multirow{2}{*}{2005} & \multirow{2}{*}{2008} & \multirow{2}{*}{2013} \\
\hline & A & B & & & & & & \\
\hline $\begin{array}{l}\text { EQUISETACEAE } \\
\text { 1. Equisetum palustre L. }\end{array}$ & 2006 & - & Ap & $\mathrm{G}$ & - & - & $\mathrm{b}$ & $\mathrm{c}$ \\
\hline $\begin{array}{l}\text { CERATOPHYLLACEAE } \\
\text { 2. Ceratophyllum demersum } \mathrm{L} \text {. }\end{array}$ & 2004 & 2005 & $\mathrm{n}-\mathrm{Sp}$ & Hy & - & $\mathrm{e}$ & $\mathrm{e}$ & $\mathrm{e}$ \\
\hline $\begin{array}{l}\text { RANUNCULACEAE } \\
\text { 3. Ranunculus repens } \mathrm{L} \text {. } \\
\end{array}$ & 2000 & 2002 & Ap & $\mathrm{H}, \mathrm{Hy}$ & $\mathrm{P}$ & $\mathrm{e}$ & e & $\mathrm{e}$ \\
\hline $\begin{array}{l}\text { URTICACEAE } \\
\text { 4. Urtica dioica } \mathrm{L} . \\
\text { BETULACEAE }\end{array}$ & 2004 & 2005 & Ap & $\mathrm{H}$ & $\mathrm{Me}$ & a & $\mathrm{b}$ & $\mathrm{c}$ \\
\hline $\begin{array}{l}\text { 5. Alnus glutinosa (L.) Gaertn. } \\
\text { CARYOPHYLLACEAE }\end{array}$ & 1965 & 2012 & Ap & M & $\mathrm{Me}, \mathrm{P}$ & $\mathrm{c}$ & $\mathrm{c}$ & $\mathrm{c}$ \\
\hline 6. Cerastium holosteoides Fr. & 2007 & 2007 & Ap & $\mathrm{C}, \mathrm{H}$ & - & - & $\mathrm{b}$ & $\mathrm{c}$ \\
\hline POLYGONACEAE & & & & & & & & \\
\hline 7. Persicaria maculosa Gray & 2003 & 2004 & Ap & $\mathrm{T}$ & - & a & $\mathrm{b}$ & $\mathrm{b}$ \\
\hline 8. Rumex hydrolapathum Huds. & 2000 & - & $\mathrm{n}-\mathrm{Sp}$ & $\mathrm{H}, \mathrm{Hy}$ & $\mathrm{Me}, \mathrm{Ne}$ & $\mathrm{b}$ & $\mathrm{b}$ & $\mathrm{b}$ \\
\hline $\begin{array}{l}\text { SALICACEAE } \\
\text { 9. Salix fragilis } \mathrm{L} . \\
\end{array}$ & 1965 & 1965 & Ap & $\mathrm{M}$ & $\mathrm{Me}, \mathrm{Ne}, \mathrm{P}$ & $\mathrm{a}$ & $\mathrm{a}$ & $\mathrm{a}$ \\
\hline BRASSICACEAE & & & & & & & & \\
\hline 10. Armoracia rusticana G. Gaertn., B. Mey. et Scherb. & - & 2004 & $\mathrm{Ar}$ & $\mathrm{G}$ & $\mathrm{Me}$ & a & $\mathrm{b}$ & $\mathrm{b}$ \\
\hline 11. Cardamine pratensis $\mathrm{L}$. & 2006 & - & Ap & $\mathrm{H}$ & $\mathrm{Me}, \mathrm{Ne}, \mathrm{P}$ & - & $\mathrm{d}$ & $\mathrm{d}$ \\
\hline 12. Rorippa amphibia (L.) Besser & 2005 & 2006 & Ap & $\mathrm{H}, \mathrm{Hy}$ & $\mathrm{Ne}$ & $\mathrm{a}$ & e & $\mathrm{e}$ \\
\hline PRIMULACEAE & & & & & & & & \\
\hline 13. Lysimachia nummularia $\mathrm{L}$. & 2006 & 2006 & $n-S p$ & $\mathrm{C}$ & $\mathrm{Me}, \mathrm{Ne}, \mathrm{P}$ & - & $\mathrm{d}$ & $\mathrm{e}$ \\
\hline 14. Lysimachia vulgaris L. & 2010 & - & $\mathrm{n}-\mathrm{Sp}$ & $\mathrm{H}$ & $\mathrm{Ne}, \mathrm{P}$ & - & - & $\mathrm{b}$ \\
\hline $\begin{array}{l}\text { FABACEAE } \\
\text { 15. Trifolium repens } \mathrm{L} \text {. }\end{array}$ & 2001 & 2003 & Ap & $\mathrm{C}, \mathrm{H}$ & $\mathrm{Me}, \mathrm{Ne}, \mathrm{P}$ & $\mathrm{e}$ & $\mathrm{e}$ & $\mathrm{e}$ \\
\hline $\begin{array}{l}\text { HALORAGACEAE } \\
\text { 16. Myriophyllum spicatum L. }\end{array}$ & 2005 & 2006 & $\mathrm{n}-\mathrm{Sp}$ & Hy & 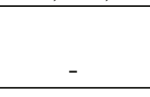 & $\mathrm{b}$ & e & e \\
\hline $\begin{array}{l}\text { LYTHRACEAE } \\
\text { 17. Lythrum salicaria L. }\end{array}$ & 2001 & 2003 & Ap & $\mathrm{H}$ & $\mathrm{Me}, \mathrm{Ne}$ & $\mathrm{c}$ & $\mathrm{b}$ & $\mathrm{b}$ \\
\hline ONAGRACEAE & & & & & & & & \\
\hline 18. Epilobium hirsutum L. & 2000 & 2004 & Ap & $\mathrm{H}$ & $\mathrm{Ne}, \mathrm{P}$ & $\mathrm{c}$ & $\mathrm{b}$ & $\mathrm{b}$ \\
\hline 19. Epilobium roseum Schreb. & 2007 & - & $\mathrm{n}-\mathrm{Sp}$ & $\mathrm{H}$ & - & - & $\mathrm{a}$ & $\mathrm{b}$ \\
\hline $\begin{array}{l}\text { BALSAMINACEAE } \\
\text { 20. Impatiens parviflora DC. }\end{array}$ & 2005 & - & $\mathrm{Kn}$ & $\mathrm{T}$ & $\mathrm{Ne}, \mathrm{P}$ & $\mathrm{a}$ & $\mathrm{c}$ & $\mathrm{d}$ \\
\hline APIACEAE & & & & & & & & \\
\hline 21. Aegopodium podagraria L. & 2006 & 2004 & Ap & $\mathrm{G}, \mathrm{H}$ & $\mathrm{Me}, \mathrm{Ne}, \mathrm{P}$ & a & $\mathrm{c}$ & $\mathrm{d}$ \\
\hline 22. Berula erecta (Huds.) Coville & 2008 & - & $\mathrm{n}-\mathrm{Sp}$ & Hy & - & - & $\mathrm{a}$ & $\mathrm{b}$ \\
\hline BORAGINACEAE & & & & & & & & \\
\hline 23. Myosotis caespitosa Schultz & 1999 & 2003 & $\mathrm{n}-\mathrm{Sp}$ & $\mathrm{H}, \mathrm{T}$ & $\mathrm{Ne}, \mathrm{P}$ & $\mathrm{d}$ & $\mathrm{d}$ & $\mathrm{d}$ \\
\hline 24. Myosotis ramosissima Rochel ex Schult. & 2010 & 2006 & $\mathrm{n}-\mathrm{Sp}$ & $\mathrm{T}$ & $\mathrm{Ne}, \mathrm{P}$ & - & $\mathrm{b}$ & $\mathrm{c}$ \\
\hline 25. Symphytum officinale L. & 2000 & 2002 & Ap & $\mathrm{G}, \mathrm{H}$ & $\mathrm{Me}, \mathrm{Ne}, \mathrm{P}$ & $\mathrm{b}$ & c & $\mathrm{c}$ \\
\hline LAMIACEAE & & & & & & & & \\
\hline 26. Glechoma hederacea L. & 2003 & 2004 & Ap & $\mathrm{G}, \mathrm{H}$ & $\mathrm{Me}, \mathrm{Ne}, \mathrm{P}$ & $\mathrm{d}$ & $\mathrm{e}$ & $\mathrm{e}$ \\
\hline 27. Lycopus europaeus L. & 2001 & 2003 & Ap & $\mathrm{H}, \mathrm{Hy}$ & $\mathrm{Me}, \mathrm{Ne}$ & $\mathrm{d}$ & $\mathrm{b}$ & $\mathrm{b}$ \\
\hline 28. Prunella vulgaris L. & 2003 & 2005 & Ap & $\mathrm{H}$ & $\mathrm{Me}, \mathrm{Ne}$ & $\mathrm{d}$ & e & e \\
\hline $\begin{array}{l}\text { PLANTAGINACEAE } \\
\text { 29. Plantago maior L. }\end{array}$ & 2002 & 2004 & Ap & $\mathrm{H}$ & $\mathrm{Me}, \mathrm{P}$ & $\mathrm{b}$ & $\mathrm{b}$ & $\mathrm{c}$ \\
\hline
\end{tabular}




\begin{tabular}{|c|c|c|c|c|c|c|c|c|}
\hline SCROPHULARIACEAE & & & & & & & & \\
\hline 30. Scrophularia umbrosa Dumort. & 2008 & - & $\mathrm{n}-\mathrm{Sp}$ & $\mathrm{H}, \mathrm{Hy}$ & $\mathrm{Ne}$ & - & a & $\mathrm{b}$ \\
\hline 31. Veronica anagallis-aquatica L. & 2005 & 2008 & $\mathrm{n}-\mathrm{Sp}$ & $\mathrm{H}$ & - & a & $\mathrm{c}$ & $\mathrm{d}$ \\
\hline 32. Veronica chamaedrys L. & 2002 & 2004 & Ap & $\mathrm{C}$ & $\mathrm{Ne}$ & $\mathrm{e}$ & $\mathrm{e}$ & $\mathrm{e}$ \\
\hline RUBIACEAE & & & & & & & & \\
\hline 33. Galium uliginosum L. & 2003 & 2004 & $\mathrm{n}-\mathrm{Sp}$ & $\mathrm{H}$ & - & $\mathrm{b}$ & $\mathrm{b}$ & $\mathrm{c}$ \\
\hline CAPRIFOLIACEAE & & & & & & & & \\
\hline 34. Sambucus nigra L. & 1981 & - & Ap & $\mathrm{N}$ & $\mathrm{Me}, \mathrm{Ne}, \mathrm{P}$ & $\mathrm{a}$ & $\mathrm{a}$ & $\mathrm{a}$ \\
\hline COMPOSITAE & & & & & & & & \\
\hline 35. Bellis perennis L. & 2002 & 2004 & Ap & $\mathrm{H}$ & $\mathrm{Me}, \mathrm{Ne}, \mathrm{P}$ & $\mathrm{e}$ & $\mathrm{e}$ & $\mathrm{e}$ \\
\hline 36. Bidens tripartita $\mathrm{L}$. & 2006 & 2006 & Ap & $\mathrm{T}$ & $\mathrm{Me}, \mathrm{Ne}, \mathrm{P}$ & - & $\mathrm{c}$ & $\mathrm{d}$ \\
\hline 37. Hieracium caespitosum Dumort. & 2003 & 2005 & Ap & $\mathrm{H}$ & - & $\mathrm{b}$ & $\mathrm{b}$ & $\mathrm{c}$ \\
\hline 38. Solidago canadensis L. & 2007 & - & $\mathrm{Kn}$ & $\mathrm{G}, \mathrm{H}$ & $\mathrm{Me}, \mathrm{Ne}$ & - & a & $\mathrm{b}$ \\
\hline 39. Sonchus arvensis L. & - & 2008 & Ap & $\mathrm{G}, \mathrm{H}$ & $\mathrm{Ne}, \mathrm{P}$ & - & a & $\mathrm{b}$ \\
\hline 40. Taraxacum officinale agg. F.H. Wigg. & 2001 & 2003 & Ap & $\mathrm{H}$ & $\mathrm{Me}, \mathrm{Ne}, \mathrm{P}$ & $\mathrm{e}$ & $\mathrm{e}$ & $\mathrm{e}$ \\
\hline 41. Tussilago farfara $\mathrm{L}$. & 2000 & 2003 & Ap & $\mathrm{G}$ & $\mathrm{Me}, \mathrm{Ne}, \mathrm{P}$ & $\mathrm{e}$ & $\mathrm{e}$ & $\mathrm{e}$ \\
\hline ALISMATACEAE & & & & & & & & \\
\hline 42. Alisma plantago-aquatica $\mathrm{L}$. & 1998 & 2001 & Ap & Hy & - & $\mathrm{c}$ & $\mathrm{d}$ & $\mathrm{e}$ \\
\hline 43. Sagittaria sagittifolia $\mathrm{L}$. & 2004 & 2006 & $\mathrm{n}-\mathrm{Sp}$ & Hy & - & $\mathrm{c}$ & $\mathrm{c}$ & $\mathrm{c}$ \\
\hline HYDROCHARITACEAE & & & & & & & & \\
\hline 44. Elodea canadensis Michx. & 2006 & 2008 & $\mathrm{Kn}$ & Hy & - & - & $\mathrm{e}$ & $\mathrm{e}$ \\
\hline POTAMOGETONACEAE & & & & & & & & \\
\hline 45. Potamogeton crispus L. & 2004 & 2005 & $\mathrm{n}-\mathrm{Sp}$ & Hy & - & $\mathrm{d}$ & $\mathrm{e}$ & $\mathrm{e}$ \\
\hline LEMNACEAE & & & & & & & & \\
\hline 46. Lemna minor $\mathrm{L}$. & 1997 & 2000 & Ap & Hy & $\mathrm{Me}$ & $\mathrm{e}$ & $\mathrm{e}$ & $\mathrm{e}$ \\
\hline 47. Lemna trisulca $\mathrm{L}$. & 2010 & - & $\mathrm{n}-\mathrm{Sp}$ & Hy & - & - & - & $\mathrm{e}$ \\
\hline 48. Spirodela polyrhiza (L.) Schleid. & 1997 & 2000 & $\mathrm{n}-\mathrm{Sp}$ & Hy & - & $\mathrm{e}$ & $\mathrm{e}$ & $\mathrm{e}$ \\
\hline JUNCACEAE & & & & & & & & \\
\hline 49. Juncus effusus L. & 2000 & 2001 & Ap & $\mathrm{H}$ & - & $\mathrm{b}$ & $\mathrm{b}$ & $\mathrm{b}$ \\
\hline CYPERACEAE & & & & & & & & \\
\hline 50. Bolboschoenus maritimus (L.) Palla & 2006 & - & $\mathrm{n}-\mathrm{Sp}$ & $\mathrm{G}, \mathrm{Hy}$ & - & - & a & $\mathrm{b}$ \\
\hline 51. Carex acutiformis Ehrh. & 2000 & - & $\mathrm{n}-\mathrm{Sp}$ & G, Hy & - & $\mathrm{c}$ & e & $\mathrm{e}$ \\
\hline 52. Carex echinata Murray & 2009 & - & $\mathrm{n}-\mathrm{Sp}$ & $\mathrm{H}$ & - & - & - & $\mathrm{c}$ \\
\hline 53. Carex pseudocyperus L. & 2000 & - & $\mathrm{n}-\mathrm{Sp}$ & $\mathrm{H}, \mathrm{Hy}$ & - & $\mathrm{c}$ & $\mathrm{c}$ & $\mathrm{c}$ \\
\hline 54. Scirpus sylvaticus $\mathrm{L}$. & 2000 & 2004 & $\mathrm{n}-\mathrm{Sp}$ & G & - & $\mathrm{c}$ & $\mathrm{d}$ & $\mathrm{e}$ \\
\hline POACEAE & & & & & & & & \\
\hline 55. Festuca pratensis Huds. & 2006 & 2006 & Ap & $\mathrm{H}$ & - & - & $\mathrm{e}$ & $\mathrm{e}$ \\
\hline 56. Festuca rubra L. & 2000 & 2001 & Ap & $\mathrm{H}$ & - & $\mathrm{e}$ & $\mathrm{e}$ & $\mathrm{e}$ \\
\hline 57. Glyceria maxima (Hartm.) Holmb. & 2000 & 2002 & $\mathrm{n}-\mathrm{Sp}$ & Hy & - & $\mathrm{b}$ & $\mathrm{d}$ & $\mathrm{e}$ \\
\hline 58. Lolium perenne $\mathrm{L}$. & 2001 & 2004 & Ap & $\mathrm{H}$ & - & $\mathrm{e}$ & $\mathrm{e}$ & $\mathrm{e}$ \\
\hline 59. Molinia caerulea (L.) Moench & 2006 & 2007 & $\mathrm{n}-\mathrm{Sp}$ & $\mathrm{H}$ & - & - & $\mathrm{c}$ & $\mathrm{e}$ \\
\hline 60. Phalaris arundinacea $\mathrm{L}$. & 1998 & - & Ap & $\mathrm{G}, \mathrm{H}$ & - & $\mathrm{c}$ & $\mathrm{d}$ & $\mathrm{d}$ \\
\hline 61. Phragmites australis (Cav.) Trin. ex Steud. & 1998 & - & Ap & $\mathrm{G}, \mathrm{Hy}$ & - & $\mathrm{d}$ & $\mathrm{e}$ & $\mathrm{e}$ \\
\hline 62. Роа аппиа $\mathrm{L}$. & 1997 & 2000 & Ap & $\mathrm{H}, \mathrm{T}$ & - & $\mathrm{e}$ & $\mathrm{e}$ & $\mathrm{e}$ \\
\hline 63. Poa trivialis $\mathrm{L}$. & 2003 & 2005 & Ap & $\mathrm{H}$ & - & $\mathrm{e}$ & $\mathrm{e}$ & $\mathrm{e}$ \\
\hline SPARGANIACEAE & & & & & & & & \\
\hline 64. Sparganium emersum Rehmann & 2007 & - & $\mathrm{n}-\mathrm{Sp}$ & Hy & - & - & a & $\mathrm{c}$ \\
\hline 65. Sparganium erectum $\mathrm{L}$. & 1999 & 2003 & $\mathrm{n}-\mathrm{Sp}$ & Hy & - & $\mathrm{b}$ & $\mathrm{d}$ & $\mathrm{e}$ \\
\hline TYPHACEAE & & & & & & & & \\
\hline 66. Typha angustifolia L. & 2001 & 2003 & Ap & $\mathrm{H}, \mathrm{Hy}$ & $\mathrm{Me}$ & $\mathrm{d}$ & $\mathrm{e}$ & $\mathrm{e}$ \\
\hline 67. Typha latifolia L. & 2002 & 2004 & Ap & $\mathrm{H}, \mathrm{Hy}$ & $\mathrm{Me}$ & $\mathrm{d}$ & $\mathrm{e}$ & $\mathrm{b}$ \\
\hline IRIDACEAE & & & & & & & & \\
\hline 68. Iris pseudacorus L. & 1998 & 2000 & $\mathrm{n}-\mathrm{Sp}$ & $\mathrm{G}, \mathrm{Hy}$ & $\mathrm{Me}, \mathrm{Ne}, \mathrm{P}$ & $\mathrm{b}$ & $\mathrm{c}$ & $\mathrm{d}$ \\
\hline
\end{tabular}


Table 2

The share of life forms and geographical-historical groups in the spontaneous flora of the water reservoirs and their wet banks in the UMCS Botanical Garden in Lublin

\begin{tabular}{|c|c|c|c|c|c|c|c|}
\hline & \multirow{3}{*}{ Life forms } & \multicolumn{4}{|c|}{ Geographical-historical groups } & \multirow{3}{*}{ Total } & \multirow{3}{*}{$\%$} \\
\hline & & \multicolumn{2}{|c|}{ Spontaneophytes (Sp) } & \multicolumn{2}{|c|}{ Antropophytes (A) } & & \\
\hline & & $\mathrm{n}-\mathrm{Sp}$ & Ap & Ar & $\mathrm{Kn}$ & & \\
\hline \multirow{2}{*}{ Phanerophytes } & Megaphanerophytes (M) & - & 2 & - & - & 2 & 3 \\
\hline & Nanophanerophytes (N) & - & 1 & - & - & 1 & 2 \\
\hline Chamaephytes & Chamaephytes (C) & 1 & 1 & - & - & 2 & 3 \\
\hline Hemicryptophytes & Hemicryptophytes $(\mathrm{H})$ & 5 & 14 & - & - & 20 & 29 \\
\hline \multirow{2}{*}{ Cryptophytes } & Geophytes (G) & 1 & 2 & 1 & - & 4 & 6 \\
\hline & Hydrophytes and helophytes (Hy) & 11 & 2 & - & 1 & 13 & 19 \\
\hline Therophytes & Therophytes (T) & 1 & 2 & - & 1 & 4 & 6 \\
\hline \multirow{7}{*}{ Other forms } & $\mathrm{C}, \mathrm{H}$ & - & 2 & - & - & 2 & 3 \\
\hline & $\mathrm{H}, \mathrm{Hy}$ & 3 & 5 & - & - & 8 & 11 \\
\hline & $\mathrm{H}, \mathrm{T}$ & 1 & 1 & - & - & 2 & 3 \\
\hline & $\mathrm{G}, \mathrm{H}$ & - & 5 & - & 1 & 6 & 9 \\
\hline & G, Hy & 3 & 1 & - & - & 4 & 6 \\
\hline & Total & 26 & 38 & 1 & 3 & 68 & 100 \\
\hline & $\%$ & 38 & 56 & 2 & 4 & 100 & - \\
\hline
\end{tabular}

Explanations of geographical-historical groups: see Table 1.

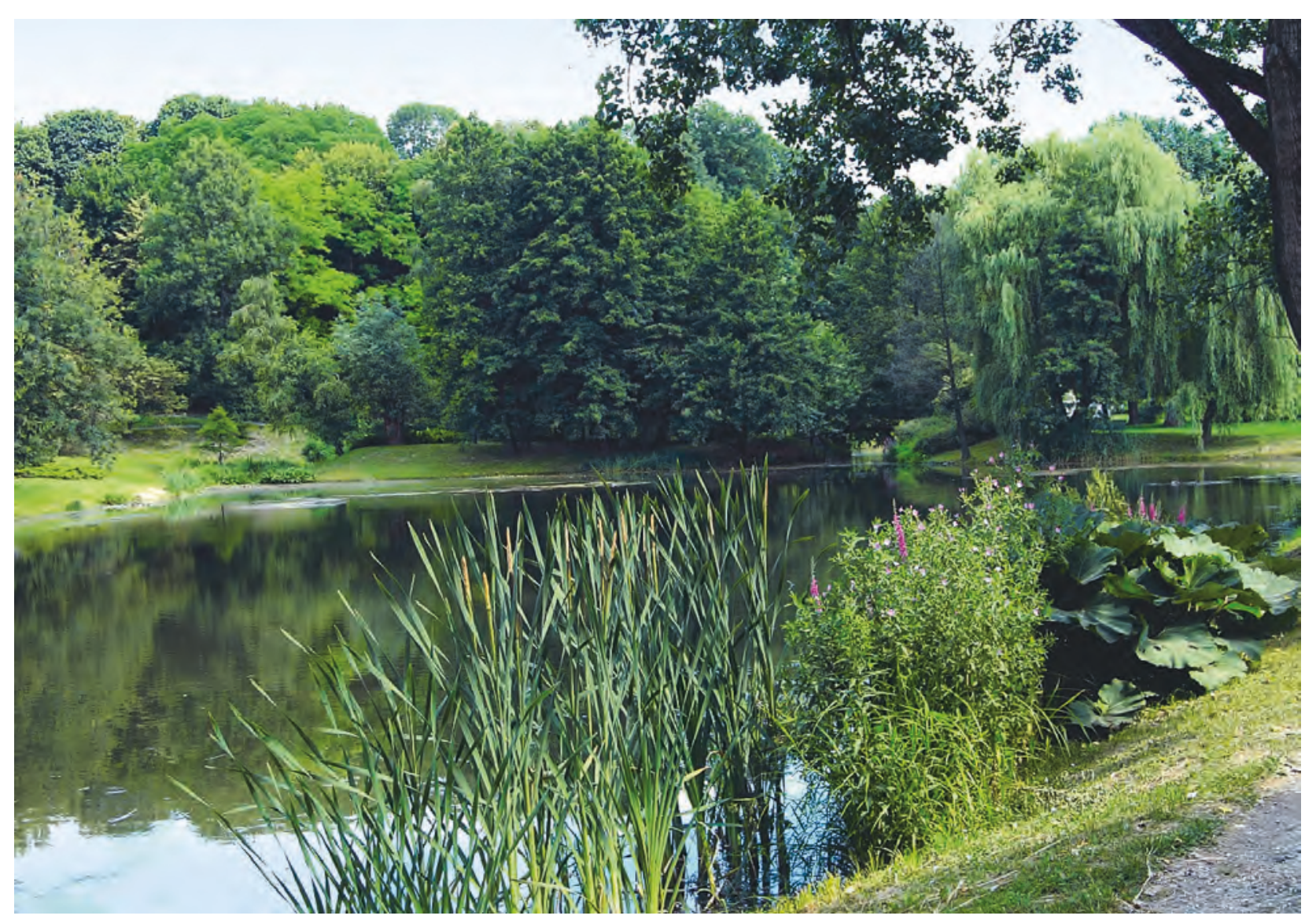

Fig. 1. View of pond A in the UMCS Botanical Garden in Lublin. 


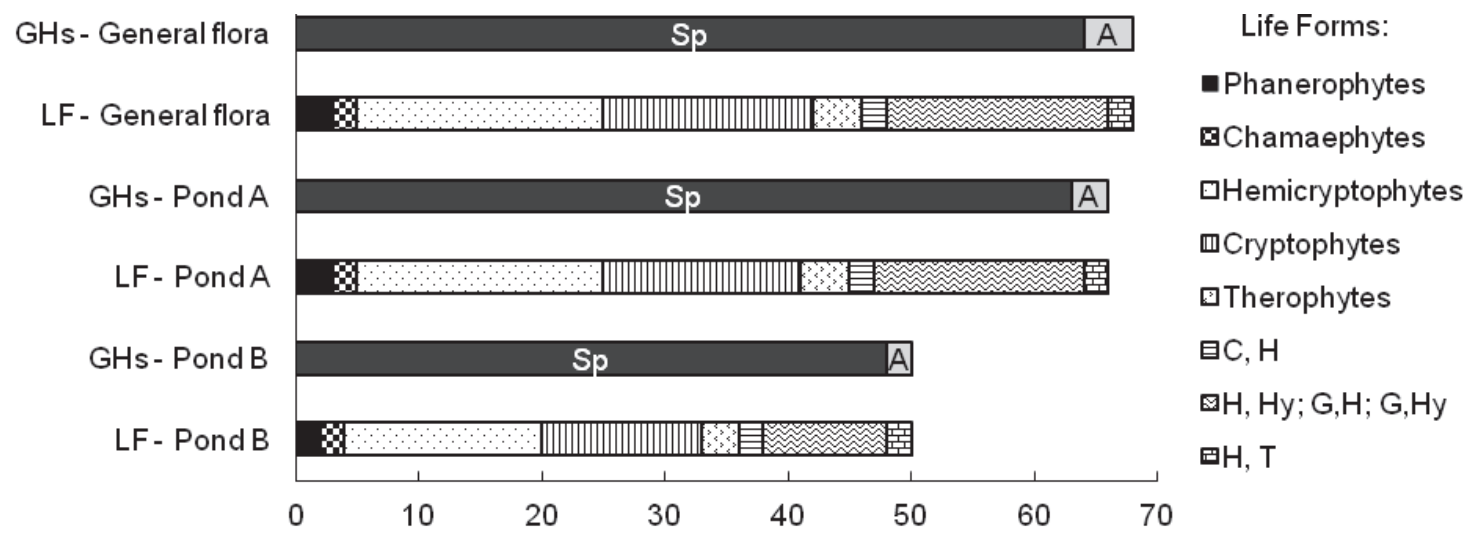

Fig. 2. The share of life forms and geographical-historical groups in the spontaneous flora of pond A and B.

The spontaneous flora of locality A comprises 66 species and locality B has 50 species. 48 taxa are common for the flora of both water bodies ( $70 \%$ of the flora) (Table 1, Fig. 2). The Jaccard species similarity index for the two localities reaches 1.4. 63 spontaneophytes and 3 anthropophytes were reported from locality A, and 48 spontaneophytes and 2 anthropophytes from locality B (Table 1, Fig. 2). The species occurring only in reservoir A (18 species) are characterised by poor growth and spread rates and form small clusters e.g. Berula erecta, Bolboschoenus maritimus, Lysimachia vulgaris, Rumex hydrolapathum, and Scrophularia umbrosa. They belong to hemicryptophytes and cryptophytes and plants exhibiting combined characteristics - H, Hy; G, H; G, Hy. The share of phanerophytes, chamaephytes, therophytes, $\mathrm{C}, \mathrm{H}$, and $\mathrm{H}$, T is comparable in both ponds (Table 1, Fig. 2). Armoracia rusticana and Sonchus arvensis occur only in locality B (Table 1).

Free-floating plants Lemna minor and Spirodela polyrhiza were the first to appear on the newly restored ponds; next, the wet zones of the ponds were gradually inhabited by Alisma plantago-aquatica, Phalaris arundinacea, Phragmites australis, Iris pseudacorus, Myosotis caespitosa, Sparganium erectum, Ranunculus repens, Juncus effusus, Carex acutiformis, Rumex hydrolapathum, Glyceria maxima, and Symphytum officinale (Table 1). Massive colonisation by new species was noted three years after revitalisation of the ponds. The intensive colonisation of locality A by spontaneophytes persisted for seven years (2000-2006) and in locality B for only four years (2003-2006) (Fig. 3). In the successive years, the number of new taxa declined considerably, until no new species were reported in the last years of the study.

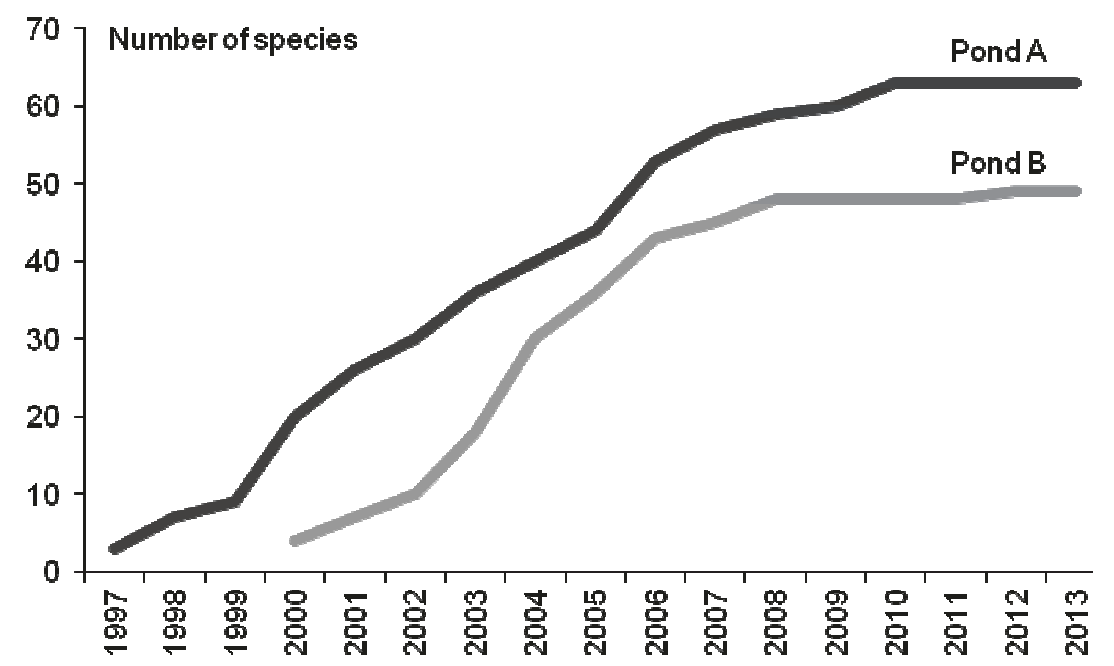

Fig. 3. The rate of spontaneous flora development in the water reservoirs and their wet banks in the UMCS Botanical Garden in Lublin. Pond A - 1997-2013. Pond B - 2000-2013.

Encroaching spontaneophytes spread rapidly in the study area, colonising free spaces in the water bodies and their littoral zones. Based on the analysis of species abundance of the spontaneous flora (Fig. 4), it was found that in 2005 the shares of species in the five consecutive groups (a-e) in the scale were roughly equ- 
al, with a slight advantage in the fifth group. In 2008 and 2013, the highest percentage was represented by highly expanding species classified in the fifth group (e-above 100 plants), while in the other groups (b-d) the number of species ranged from 8 to 15 (Table 1, Fig. 4). In 2013 only two phanerophytes, Salix fragilis and Sambucus nigra, were classified in the first group (a), whereas 30 species (44\% of the investigated flora) belonged to the fifth group (e). In the last year of the study, the water bodies were dominated by free-floating plants from the class Lemnetea R. Tx. 1955, e.g. Lemna minor, Lemna trisulca, and Spirodela polyrhiza, and submerged plants from the class Potamogetonetea
R. Tx. et Prsg., e.g. Ceratophyllum demersum, Elodea canadensis, Myriophyllum spicatum, and Potamogeton crispus. The littoral zone comprised numerous Alisma plantago-aquatica, Carex acutiformis, Glyceria maxima, Molinia caerulea, Phragmites australis, Ranunculus repens, Rorippa amphibia, Scirpus sylvaticus, Sparganium erectum, and Typha angustifolia. The banks of the water reservoirs were dominated by grasses Festuca pratensis, Festuca rubra, Lolium perenne, Poa аппиа, and Poa trivialis, with a substantial share of Bellis perennis, Glechoma hederacea, Lysimachia nummularia, Prunella vulgaris, Taraxacum officinale, Trifolium repens, Tussilago farfara, and Veronica chamaedrys.

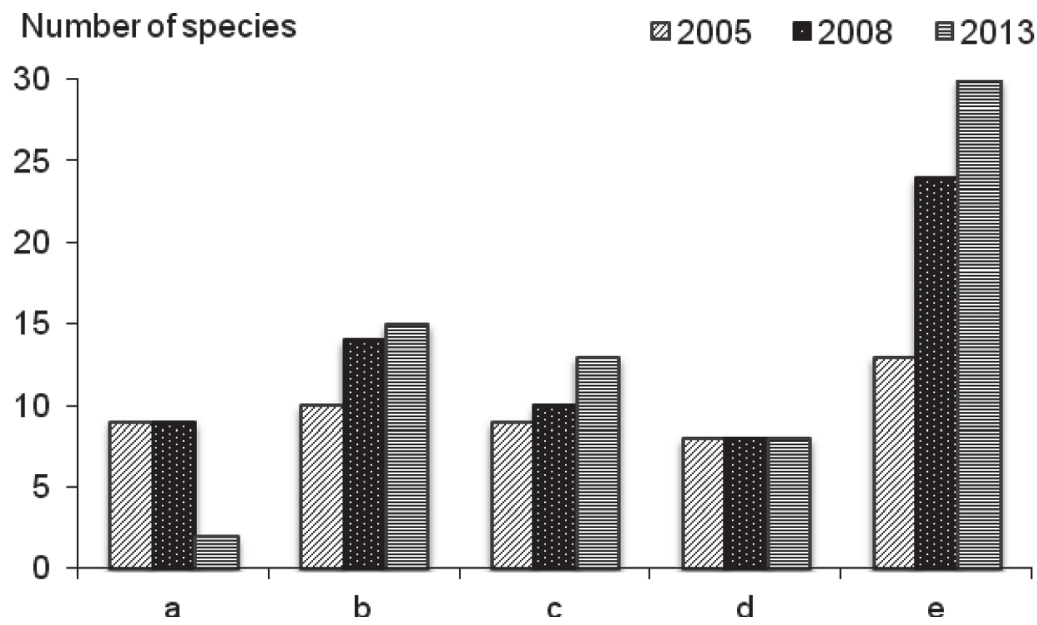

Fig. 4. Changes in the abundance of spontaneous flora in the water reservoirs and their wet banks in the UMCS Botanical Garden in Lublin in the years 2005, 2008, 2013. Abundance: a - 1-5 plants; b - 6-20 plants; c - 21-50 plants; d - 51-100 plants; e - above 100 plants.

The flora of the ponds and their wet zone comprised 25 medicinal plants, 19 nectariferous and polleniferous species, 8 species providing bees with only nectar, and 3 only polleniferous species (Table 1). The lowest number of medicinal plants and bee forage flora was noted among monocots. In contemporary medicine, approximately 15 described taxa are used, e.g. Alnus glutinosa and Iris pseudacorus. The most valuable melliferous plants strictly associated with aquatic environments include Cardamine pratensis, Epilobium hirsutum, Lycopus europaeus, Lythrum salicaria, Myosotis caespitosa, Rorippa amphibia, Scrophularia umbrosa, and Rumex hydrolapathum. They are scattered, but their successive flowering between early spring and late summer provides bees with sufficient forage.

\section{DISCUSSION}

Small water reservoirs located within urban developments primarily serve an aesthetic and recreational function. However, excessive human interference has disturbed the biotic conditions in such reservoirs. Eutrophication and pollution of surface waters lead to inhibited development of flora and fauna, resulting in their complete elimination from aquatic environments [7,22-24]. Urban water bodies situated in densely built-up areas do not have a high natural value and their floristic composition is very poor. The rush community includes Phragmites australis and Typha angustifolia, and the submerged vegetation zone comprises Potamogeton crispus and Ceratophyllum demersum $[25,26]$. The water table of these reservoirs is dominated by floating plant communities from the class Lemnetea R. Tx. 1955, usually by Lemna minor often accompanied by Spirodela polyrhiza. During the growing season, these communities usually cover the entire water surface, thereby preventing the development of submerged plants and succession of shoreline vegetation.

Urban reservoirs are often maintained in good condition thanks to appropriate treatment practices such as dredging and vegetation spread (overgrowth) control. Examples of such water bodies located within 
large urban agglomeration areas include the reservoirs in the left-bank Warsaw [27] as well as in the centre of Szczecin [28] and Poznań [26]. The reservoirs located in the western part of Lublin can be included in this group of water bodies. Despite the similar ecological conditions prevailing in these water bodies, the inventory of spontaneous vegetation in the Lublin reservoirs is four-fold greater than that recorded in the water bodies of Warsaw, Szczecin, or Poznań. A high level of eutrophication in urban reservoirs has an adverse effect on biodiversity. Ceratophyllum demersum, Lemna minor, Myriophyllum spicatum, Phragmites australis, Potamogeton crispus, Spirodela polyrhiza, Typha angustifolia, and Typha latifolia are characterised by the greatest expansion. These species are often a major component of the spontaneous flora of these water bodies.

Detailed floristic investigations often indicate a high range of anthropophytisation index values. The highest values of this index are reported from the centres of large cities [29]. In contrast, the index values in the Vistula River valley ranged between $11 \%$ and $31 \%$ [4], whereas at the study sites in the Czechówka River valley the index reached a value of $6 \%$.

Despite human economic activity and natural processes, the areas of big cities still comprise water bodies that have a great natural and landscape value and provide a habitat for medicinal and bee forage plants [7]. These sites are usually under different forms of protection, which ensures their conservation. The Lublin reservoirs analysed comprise 25 medicinal plant species (37\% of the spontaneous flora). The share of these plants in the investigated flora is high, considering the size of the study area. For comparison, the vast meadows and peatlands of Łęczna-Włodawa Lakeland near Lublin were reported to comprise 88 medicinal plant species [30], while the entire Lubelszczyzna region -537 species [31]. Small enclaves of vegetation in cities are a source of valuable and diverse bee forage [32]. Similarly, small plant communities in agricultural landscape, i.e. baulks, mid-field woodlots and fallows, are important refuge areas for forage vegetation [33]. These habitats increase the floristic biodiversity of these areas and simultaneously provide multispecies forage beneficial for bee development. The biotopes analysed comprised 19 bee forage species representing $28 \%$ of the flora.

Small water bodies located in the centres of large cities are characterised by strong anthropogenic transformation. They usually comprise poor spontaneous flora typically dominated by several plant species, e.g. Glyceria maxima, Lemna minor, Myriophyllum spicatum, Phragmites australis, Potamogeton crispus, Spirodela polyrhiza, Typha angustifolia, and Typha latifolia.

\section{CONCLUSIONS}

1. Within 16 years, 68 aquatic, marsh, reed, and hygrophilous plants colonised the restored water reservoirs and their littoral zones. Thirty of them spread expansively, forming fragmentary plant communities and thus preventing succession of the other spontaneophytes.

2. The spontaneous flora of the investigated ponds is dominated by native species, which account for $94 \%$ of the flora.

3 . The relatively rich species composition of the investigated sites is accompanied by a low proportion of anthropophytes, which is implied by the lower anthropophytisation index, compared to reservoirs in other cities.

4. The biological spectrum is characterised by the dominance of perennials (cryptophytes and hemicryptophytes) over the other life forms.

5. The proportion of species in the spontaneous flora of the small water reservoirs in Lublin is four-fold higher than that in similar urban water bodies in Warsaw, Szczecin, or Poznań. A common feature of urban water reservoirs is their poor floristic composition, primarily consisting of several expansive plant species, e.g. Glyceria maxima, Lemna minor, Myriophyllum spicatum, Phragmites australis, Potamogeton crispus, Spirodela polyrhiza, Typha angustifolia, and Typha latifolia colonising the entire reservoirs.

\section{Acknowledgements}

Research supported by the Ministry of Science and Higher Education of Poland as part of the statutory activities of the Botanical Garden, Maria Curie-Skłodowska University in Lublin.

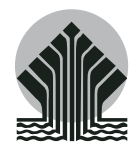

Co-financed by National Fund

for Environmental Protection and Water Management

\section{REFERENCES}

1. Burkart M. River corridor plants (Stromtalpflanzen) in Central European lowland: a review of a poorly understood plant distribution pattern. Global Ecol. Biogeogr. 2001; 10: 449-468. http://dx.doi.org/10.1046/j.1466-822x.2001.00270.x

2. Ku ch a rczyk M. Doliny rzeczne jako ośrodki różnorodności i drogi rozprzestrzeniania się roślin - jakie znaczenie ma wielkość rzeki. [In:] Kozłowski S, Kuśmierczyk J, (eds) Bug. Rzeka, która łączy. Piaski: Ekologiczny Klub UNESCO, Pracownia na rzecz bioróżnorodności; 2002: 58-69. (in Polish) 
3. Dąbrowska A, Kwiatkowski M. Water and marsh plants in the Botanical Garden of Maria Curie-Sklodowska University in Lublin, Poland. Proceedings of international scientific conference devoted to the 50th anniversary of high-mountain „Pozhyzhevska” biological station ,Significance and prospects of stationary research on conservation of biodiversity”. Lviv-Pozhyzhevska; 2008. p. 120-121.

4. Kucharczyk M. Analysis of distribution of antropophytes in the Vistula River valley. In: Zając A, Zając M, Zemanek B, editors. Phytogeographical problems of synanthropic plants. Cracow: Institute of Botany, Jagiellonian University; 2003. p. 295-300.

5. Fudali E. Antropogeniczne zmiany w ekosystemach. Transformacje roślinności. Wrocław: Wyd. UP we Wrocławiu; 2009. (in Polish)

6. Chmielewski S, Chmielewski TJ. Zmiany zagospodarowania przestrzennego doliny rzeki Czechówki w procesie rozwoju miasta Lublina w latach 1931-2002 i możliwości jej przyrodniczej rewitalizacji. / Changes in spatial arrangement of Czechówka River valley in the process of Lublin development in the years 1931-2002 and the opportunities of its ecological revitalization. Teka Kom. Arch. Urb. Stud. Krajobr. OL PAN; 2005: 183-195. (in Polish)

7. Nowacka-Rejzner U. Stawy i tereny podmokłe w obszarze miasta. Dialog z przyrodą czy dominacja urbanizacji? Ponds and wetlands in metropolitan areas. / Dialog with the nature or the domination of urbanization? Czasopismo techniczne. Wyd. Polit. Krak. 2007; 7a: 127-134. (in Polish)

8. Michalczyk Z, editor. Strategia wykorzystania i ochrony wód w dorzeczu Bystrzycy. Badania hydrograficzne w poznaniu środowiska 5. Lublin: Wyd. UMCS Lublin; 1997. (in Polish)

9. Michalczyk Z, Chmiel S, Głowacki S. Przepływy rzek w aglomeracji lubelskiej w latach 20082012. [In:] Michalczyk Z, editor. Ocena warunków występowania wody i tworzenia się spływu powierzchniowego w Lublinie. Badania hydrograficzne w poznawaniu środowiska. Lublin: Wyd. UMCS Lublin; 2012. p. 145-160. (in Polish)

10. Kw i at kow ski M. Sposób odtworzenia zbiorników wodnych w Ogrodzie Botanicznym UMCS. Biuletyn Ogrodów Bot., Muzeów i zbiorów. 1997; 6: 49-53. (in Polish)

11. Kozak K. Stawy jako jeden z pierwszych obiektów w Ogrodzie Botanicznym UMCS na Sławinku. Wiad. Bot. 1968; 12(2): 148-150. (in Polish)

12. Index Kewensis - www.theplantlist.org

13. Chmiel J. Flora roślin naczyniowych wschodniej części Pojezierza Gnieźnieńskiego i jej antropogeniczne przeobrażenia w wieku XIX i XX 1, 2. Prace Zakładu Taksonomii Roślin UAM w Poznaniu. Poznań: Wyd. Sorus; 1993. (in Polish)

14. Jackowiak B. Antropogeniczne przemiany flory roślin naczyniowych Poznania. Poznań: Ser. Biol. 42. Wyd. Nauk. UAM; 1990. (in Polish)

15. Zając A. Pochodzenie archeofitów występujących w Polsce. Zesz. Nauk. Uniw. Jagiellońskiego, Rozpr. Habil. 29; 1979. (in Polish)
16. Zając A, Zając M, Tokarska-Guzik B. Kenophytes in the flora of Poland: list, status and origin. Phytocoenosis 10, Suppl. Cartograph. Geobot. 1998; 9: 107-116.

17. Zarzycki K, Trzcińska-Tacik H, Różański W, Szeląg Z, Wołek J, Korzeniak U. Ecological indicator values of vascular plants of Poland. Cracow: W. Szafer Institute of Botany, Polish Academy of Sciences; 2002.

18. Podbielkowski Z, Sudnik-Wójcikowska B. Słownik roślin użytkowych. Warszawa: Wyd. VII. PWRiL; 2003. (in Polish)

19. Kołt ow ski Z. Wielki Atlas Roślin Miododajnych. Warszawa: Przeds. Wyd. Rzeczpospolita; 2006.

20. Li pi ń sk i M. Pożytki pszczele zapylenie i miododajność roślin. Stróże: PWRiL, Warszawa, Wyd. Sądecki Bartnik; 2010. (in Polish)

21. Kornaś J. Analiza flor synantropijnych. Wiad. Bot. 1977; 21(2): 85-91. (in Polish)

22. Skwierawski A. Funkcjonowanie małych zbiorników wodnych w różnych typach krajobrazu 8. In: Koc J, editor. Współczesne problemy kształtowania i ochrony środowiska. Ochrona zasobów i jakości wody w krajobrazie wiejskim, Monografie 1p. Olsztyn: Uniw. W-M; 2010. p. 175-195. (in Polish)

23. Jurczak T, Wagner I, Zalewski M, editor. Ekohydrologiczna rekultywacja zbiorników rekreacyjnych Arturówek (Łódź) jako modelowe podejście do rekultywacji zbiorników miejskich (EH-REK). Analiza zagrożeń i szans. Łódź: PROXIMA Sp. z o.o; 2012. (in Polish)

24. Dąbkowski S L, Rydałowski M, Szymczuk P. Miejski staw bezodpływowy jako odbiornik ścieków deszczowych (na przykładzie Stawu Koziorożca w warszawskiej dzielnicy Włochy). / Urban pond without outflow as a resiver of rainwater (Koziorożec Pond example in the Włochy district in Warsaw). Woda - Środowisko - Obszary Wiejskie 13. 2013; 3(43): 23-40. (in Polish)

25. Nuckowska K, Krzyża nowska I. Fauna and flora in two city-centre water reservoirs in Gorzów Wielkopolski. Teka Kom. Ochr. Kszt. Środ. Przyr. 2006; 3: 153-159.

26. Świerk D, Szpakowska B. Ocena wartości rekreacyjnej wybranych zbiorników miejskich a funkcjonowanie strefy litoralnej. / Estimation of recreational values of chosen water reservoirs and littoral zone functioning. Nauka Przyr. Technol. 2009; 3(1): \#51. (in Polish)

27. St ańczyk T, Jezna ch J. Charakterystyka zbiorników wodnych lewobrzeżnej Warszawy. Rocz. AR Poz. Melior. Inż. Środ. 2005; 26: 427-434. (in Polish)

28. P i e si k J . Małe zbiorniki wodne w krajobrazie Szczecina. / Small reservoirs in the landscape of Szczecin. Nauka Przyr. Technol. 2009; 3(1) \#28. (in Polish)

29. Sudnik-Wójcikowska B. Czasowe i przestrzenne aspekty procesu synantropizacji flory na przykładzie wybranych miast Europy Środkowej. Warszawa: Wyd. Uniw. Warszawskiego; 1998. (in Polish)

30. Sugier P, Sugier D. Richness of medicinal plants of the peatlands in the Łęczna-Włodawa Lakeland. Teka Kom. Ochr. Kszt. Środ. Przyr. OL PAN 2009; 6: 345-352. 
31. Fijałkowski D, Chojnacka-Fijałkowska E. Rośliny lecznicze na Lubelszczyźnie. Lublin: LTN; 2009. (in Polish)

32. Pog or zele c M. Chrońmy miejskie enklawy roślinności rodzimej. Pszczelarstwo. 2013; 2: 18. (in Polish)

33. Denisow B, Wrzesień M. The anthropogenic refuge areas for bee flora in agricultural landscape. Acta Agrobot. 2007; 60(1): 147-159. http://dx.doi.org/10.5586/ aa. 2007.018

\section{Charakterystyka roślin wodnych i wilgociolubnych zbiorników wodnych w Ogrodzie Botanicznym UMCS w Lublinie, Polska}

Streszczenie

Celem pracy była inwentaryzacja i charakterystyka ekologiczna spontanicznie wykształconej flory w odtworzonych zbiornikach wodnych i ich wilgotnych brzegach w zachodniej części Lublina w latach 19972013. Badane obiekty są niewielkimi zbiornikami położonymi w Ogrodzie Botanicznym UMCS w dolinie rzeki Czechówki. Stawy znajdują się pod silnym wpływem człowieka. We florze zbiorników i na ich wilgotnych brzegach odnotowano 68 gatunków roślin (z 33 rodzin i 58 rodzajów). Istotną cechą opisywanych obiektów jest duży udział gatunków rodzimych (94\% flory). Wśród form życiowych dominują kryptofity i hemikryptofity oraz grupy biologiczne łączące cechy hemikryptofitów oraz kryptofitów. Byliny łącznie stanowią $80 \%$ flory. Stawy i ich bagniste brzegi stanowią miejsce występowania 25 gatunków roślin o działaniu leczniczym i 19 gatunków roślin pożytkowych dla owadów.

Handling Editor: Elżbieta Weryszko-Chmielewska

This is an Open Access digital version of the article distributed under the terms of the Creative Commons Attribution 3.0 License (creativecommons.org/licenses/by/3.0/), which permits redistribution, commercial and non-commercial, provided that the article is properly cited. 